
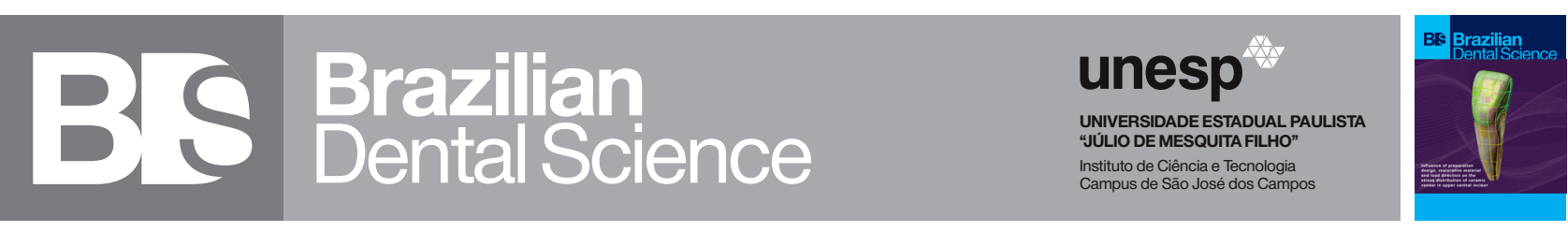

\title{
Efficacy of fluoride varnishes with different compositions on white spot lesions remineralization
}

\author{
Eficácia de vernizes fluoretados com diferentes composições na remineralização de manchas brancas
}

Carlos Rocha Gomes TORRES ${ }^{1}$, Manuela da Silva SPINOLA ${ }^{1}$, Renata Falchete do PRADO ${ }^{1}$, Vinicius Anéas RODRIGUES ${ }^{2}$, Natália Cortez GUTIERREZ ${ }^{1}$, Alessandra Buhler BORGES ${ }^{1}$

1 - São Paulo State University (Unesp), Institute of Science and Technology, Department of Restorative Dentistry, São José dos Campos, Brazil.

2 - Department of Prosthodontics, University Center Funvic - UniFunvic, Pindamonhagaba, Brazil.

\begin{abstract}
Objective: To evaluate the efficacy of different fluoride varnishes on white spot lesions (WSL) remineralization. Material and Methods: Polished bovine enamel specimens were obtained $(n=60)$ and had their initial surface Knoop microhardness (SMH) determined. WSL were created and the SMH was measured again. Then, specimens were allocated into six groups: $\mathrm{C}-$ Control (without varnish); $\mathrm{BF}-$ Bifluorid 12 (6\% NaF + 6\% CaF2); DP - Duraphat (5\% NaF); PF - Profluorid (5\% NaF); FP - Fluor Protector $(0.2 \% \mathrm{NaF}+0.9 \%$ difluorsilane $)$; $\mathrm{CW}$ Clinpro White Varnish (5\% NaF + 5\% TCP). After varnishes application, specimens were immersed in artificial saliva for $24 \mathrm{~h}$. Then, pH-cycling was performed for 8 days and SMH was measured. Data were analyzed by one-way ANOVA and Tukey's test. Results: Non-significant differences were observed among the groups at baseline $(p=0.187)$ and after WSL formation $(p=0.999)$. After treatments, significant differences were observed among the groups ( $p=0.001)$. Mean $\%$ of alteration $(S D)$ and results of Tukey test were: C- 92.40 (12.10)a; PF88.66 (10.66)a; FP- 85.90 (14.49)ab; BF- 67.85 (17.86)bc; CW- 66.60 (18.48)c; DP- 58.62 (8.69) c. Conclusion: Bifluorid 12, Clinpro White Varnish, and Duraphat showed higher efficacy than artificial saliva in promoting the remineralization of WSL, nevertheless, none of the treatments were able to recover sound enamel baseline microhardness.
\end{abstract}

\section{KEYWORDS}

Dental caries; Fluoride; Fluoride varnishes.

\section{RESUMO}

Objetivo: Avaliar a eficácia de diferentes vernizes fluoretados na remineralização de lesões de mancha branca (LMB). Material e métodos: Espécimes de esmalte bovino polido $(\mathrm{n}=60)$ foram submetidos à análise de microdureza superficial Knoop (KMH) inicial. Foram então criadas LMB artificialmente e os espécimes foram alocados em seis grupos: C Controle (sem aplicação de verniz); BF - Bifluorid 12 (6\% NaF + 6\% CaF2); DP - Duraphat (5\% NaF); PF - Profluorid (5\% NaF); FP - Fluor Protector $(0.2 \% \mathrm{NaF}$ $+0.9 \%$ difluorsilano); CW - Clinpro White Varnish ( $5 \% \mathrm{NaF}+5 \% \mathrm{TCP})$. Após a aplicação dos vernizes, os espécimes ficaram imersos em saliva artificial por $24 \mathrm{~h}$ e uma ciclagem de $\mathrm{pH}$ foi realizada por 8 dias. Após a ciclagem, KMH final foi realizada. Os dados foram analisados por ANOVA e teste de Tukey (5\%). Resultados: Não foi observada diferença significante para os grupos após a KHM inicial $(\mathrm{p}=0.187)$ e após a formação de LMB ( $p=0.999)$. Após os tratamentos, diferenças significativas foram observadas entre os grupos $(\mathrm{p}=0.001)$. Valores de média de $\%$ de alteração superficial (desvio-padrão) e resultados do teste de Tukey foram: C- 92.40 (12.10)a; PF88.66 (10.66)a; FP- 85.90 (14.49)ab; BF- 67.85 (17.86)bc; CW- 66.60 (18.48)c; DP- 58.62 (8.69)c. Conclusão: Os vernizes Bifluorid 12, Clinpro White Varnish e Duraphat apresentaram maior eficácia na remineralização das LMB quando comparados à saliva artificial, entretanto, nenhum dos produtos testados foi capaz de recuperar os valores iniciais de microdureza.

\section{PALAVRAS-CHAVE}

Cárie dentária; Flúor; Verniz fluoretado. 


\section{INTRODUCTION}

$\mathrm{T}$ he fluoride varnishes efficacy on preventing, arresting, and remineralizing initial carious lesions is well established in literature [1]. Its remineralizing and anticaries effect are related to the precipitation of calcium fluoride-like deposits $\left(\mathrm{CaF}_{2}\right)$ on dental surfaces acting as a reservoir that slowly releases fluoride over time to interact with de- and remineralization processes [2].

Fluoride varnishes are basically delivery vehicles for high amounts of fluoride and usually contain $5 \%$ sodium fluoride (NaF) in its formula [1]. Although $\mathrm{NaF}$ is present in high concentrations, only $17 \%$ of the total fluoride is reported to be soluble to react with tooth surface [3]. The insoluble fluoride is slowly dissolved and released over time during the contact with dental surfaces and this is the major advantage of fluoride varnishes when compared to other topical fluoride protocols used on white spot lesions, like fluoride solutions and gels [4].

The amount of fluoride released over time as well as the kinetics of fluoride release is proved to be related to the different compositions, physical properties, and the presence of different active ingredients besides fluoride [5]. Lately, many sodium fluoride-based products have been supplemented with promising remineralizing substances, such as calcium fluoride, tri-calcium-phosphate (TCP), fluorsilane, xylitol and bioactive particles as an attempt to intensify its efficacy [6-11]. Nevertheless, evidence of this supposed improvement caused by addition of these ingredients are still poor and not well established in literature.

Therefore, the aim of this study was to evaluate the efficacy of fluoride varnishes containing different compounds (sodium fluoride, calcium fluoride, difluorsilane and TCP) on white spot lesions (WSL) remineralization. The null hypothesis tested was that there is no difference in the ability of the tested varnishes to remineralize incipient carious lesions.

\section{MATERIAL AND METHODS}

\section{Ethical aspects}

The present study was performed using bovine teeth and did not need approval by the Ethical
Committee, according to the Federal law \#11.794 (Arouca law - 2008), which regulates the scientific use of animals in Brazil.

\section{Enamel specimen's preparation}

Cylindrical enamel specimens $(3 \mathrm{~mm}$ diameter) obtained from freshly extracted bovine incisors were prepared from the labial surface of crowns, using a custom-made diamond trephine mill. The specimens were embedded in acrylic resin (Jet, Clássico, São Paulo, SP, Brazil) using a silicon mold, and were then polished with the aid of a metal holder and aluminum oxide abrasive papers (\#1200, 2400 and 4000; FEPA-P, Struers, Ballerup, Denmark) in a polishing device (DP-10, Panambra Industrial e Tecnica SA, São Paulo, SP, Brazil). After each grind paper, specimens were sonicated in deionized water for $5 \mathrm{~min}$. The prepared specimens were examined in stereomicroscope (20X - Carl Zeiss, Stemi 2000, Tokyo, Japan) to verify the absence of cracks or other surface defects and then stored in ultrapure water to prevent dehydration $[12,13]$.

\section{Microhardness measurement}

The microhardness determination was performed with a Knoop microhardness tester (FM700, Future-Tech,Tokyo, Japan) fitted with a 50 $\mathrm{g}$ load, which was used to make indentations on enamel surface. The load was applied during $10 \mathrm{~s}$. Three indentations ( $100 \mu \mathrm{m}$ distant from each other) were performed in each specimen and then averaged to determine the enamel surface microhardness $(\mathrm{SMH})$ at baseline $[12,13]$.

\section{Specimens' Demineralization}

Artificial enamel subsurface carious lesions were created by immersing the specimens in an acidic demineralizing solution for 21 days containing $3 \mathrm{mM}$ $\mathrm{CaCl}_{2} \cdot 2 \mathrm{H}_{2} \mathrm{O}, 3 \mathrm{mM} \mathrm{KH}_{2} \mathrm{PO}_{4}$ and $50 \mathrm{mM} \mathrm{CH}_{3} \mathrm{COOH}$, under constant agitation [14]. The proportion of demineralizing solution per area of enamel was $6.25 \mathrm{~mL} / \mathrm{mm}^{2}$ [15]. After demineralization, a new microhardness measurement was performed and the SMH values were used to allocate the samples into six groups $(\mathrm{n}=10)$ : $\mathrm{C}$ - negative control (without varnish application); DP- Duraphat ${ }^{\mathrm{TM}}$ (positive control - Colgate, 5\% NaF); PF- Profluorid ${ }^{\mathrm{TM}}$ (Voco, $5 \% \mathrm{NaF}$ ); BF- Bifluorid $12^{\mathrm{Tm}}$ (Voco, $6 \% \mathrm{NaF}+6 \%$ 
$\mathrm{CaF}_{2}$ ); FP- Fluor Protector ${ }^{\mathrm{TM}}$ (Ivoclar, Vivadent, 0.9\% Fluorsilane); CW- Clinpro White Varnish ${ }^{\mathrm{TM}}$ (3M/ ESPE, 5\% NaF + Tri-Calcium Phosphate - TCP).

\section{Fluoride varnishes application}

The products were applied according to manufacturer's instructions. The products tested, their specifications and manufacturer's instructions for application are described in Table I. After varnishes application, specimens were immersed in artificial saliva for $24 \mathrm{~h}$ so that the varnishes could reach its maximum capacity of reactivity with enamel [16]. No treatment was applied to the control group. The varnishes were then carefully removed using a cotton swab with acetone followed by immersion in deionized water.

Table I - List of the varnishes tested in the study and their composition, according to manufactures

\begin{tabular}{|c|c|c|c|c|}
\hline Product & $\begin{array}{l}\text { Manufac- } \\
\text { turer }\end{array}$ & Instructions for use & $\begin{array}{l}\text { Fluoride } \\
\text { concen- } \\
\text { tration } \\
(\%)\end{array}$ & $\begin{array}{c}\text { Additional } \\
\text { active } \\
\text { ingredients }\end{array}$ \\
\hline Duraphat & $\begin{array}{l}\text { Colgate - Pal- } \\
\text { molive (New } \\
\text { York - USA) }\end{array}$ & $\begin{array}{l}\text { - Clean and dry tooth } \\
\text { surface; } \\
\text { - Apply an evenly layer } \\
\text { over the tooth with a micro } \\
\text { applicator; }\end{array}$ & $5 \% \mathrm{NaF}$ & - \\
\hline Profluorid & $\begin{array}{l}\text { Voco (Cuxha- } \\
\text { ven - Ger- } \\
\text { many) }\end{array}$ & $\begin{array}{l}\text { - Clean and dry tooth } \\
\text { surface; } \\
\text { - Apply an evenly layer } \\
\text { over the tooth with a micro } \\
\text { applicator. }\end{array}$ & $5 \% \mathrm{NaF}$ & - \\
\hline $\begin{array}{l}\text { Cilinpro Whi- } \\
\text { te Varnish }\end{array}$ & $\begin{array}{l}\text { 3M/ESPE (St. } \\
\text { Paul - USA) }\end{array}$ & $\begin{array}{c}\text { - Clean and dry tooth } \\
\text { surface; } \\
\text { - Open the unit-dose packa- } \\
\text { ge and dispense the content } \\
\text { onto the round application } \\
\text { guide on the back of the foil } \\
\text { pouch box; } \\
\text { - Use the applicator brush to } \\
\text { thoroughly mix the varnish; } \\
\text { - Apply an evenly layer } \\
\text { over the tooth with a micro } \\
\text { applicator. }\end{array}$ & $5 \% \mathrm{NaF}$ & $\begin{array}{c}<5 \% \text { Tri-Cal- } \\
\text { cium Phosphate }\end{array}$ \\
\hline Bifluorid 12 & $\begin{array}{l}\text { Voco (Cuxha- } \\
\text { ven-Ger- } \\
\text { many) }\end{array}$ & $\begin{array}{c}\text { - Clean and dry tooth } \\
\text { surfaces; } \\
\text { - Shake biofluorid } 12 \text { con- } \\
\text { tainer; } \\
\text { - Apply an evenly layer } \\
\text { over the tooth with a micro } \\
\text { applicator. }\end{array}$ & $6 \% \mathrm{NaF}$ & $\begin{array}{l}\text { 6\% Calcium } \\
\text { Fluoride }\end{array}$ \\
\hline $\begin{array}{c}\text { Fluor } \\
\text { Protector }\end{array}$ & $\begin{array}{c}\text { Ivoclar } \\
\text { Vivadent } \\
\text { (Liechtenstein } \\
\text {-Swiss) }\end{array}$ & $\begin{array}{l}\text { - Clean and dry tooth } \\
\text { surface; } \\
\text { - Open the ampoule con- } \\
\text { taining the varnish; } \\
\text { - Apply an evenly layer } \\
\text { over the tooth with a micro } \\
\text { applicator. }\end{array}$ & $0.2 \% \mathrm{NaF}$ & $\begin{array}{l}0.9 \% \text { Difluoro- } \\
\text { silane }\end{array}$ \\
\hline
\end{tabular}

\section{$\mathrm{pH}$ cycling regimen}

The $\mathrm{pH}$-cycling $(2 \mathrm{~h}$ in the demineralizing solution and $22 \mathrm{~h}$ in the remineralizing solution) was performed for 8 days [17]. The demineralizing solution ( $\mathrm{pH}$ 5.0) was composed by $0.05 \mathrm{~mol} / \mathrm{L}$ acetate buffer obtained from dissolution of acetic acid and $1.28 \mathrm{mmol} / \mathrm{L} \mathrm{Ca}$, $0.74 \mathrm{mmol} / \mathrm{L} \mathrm{P}$, and $0.03 \mu \mathrm{g} \mathrm{F} / \mathrm{mL}$ prepared from the salts $\mathrm{Ca}\left(\mathrm{NO}_{3}\right) 2.4 \mathrm{H}_{2} \mathrm{O}, \mathrm{KH}_{2} \mathrm{PO}_{4}$ and $\mathrm{NaF}$, respectively. The remineralizing solution $(\mathrm{pH}$ 7.0) consisted of $1.5 \mathrm{mmol} / \mathrm{L} \mathrm{Ca}, 0.9 \mathrm{mmol} / \mathrm{L} \mathrm{P}$, $150 \mathrm{mmol} / \mathrm{L} \mathrm{KCl}, 0.05 \mu \mathrm{g} \mathrm{F} / \mathrm{mL}$ in $0.1 \mathrm{~mol} / \mathrm{L}$ of Tris buffer [18]. After four days of $\mathrm{pH}$ cycling, the solutions were renewed. At the end of the ph-cycling, SMH was measured again, exactly as described above to determine the enamel surface Knoop microhardness after treatments. The $\%$ of SMH alteration were calculated using the following formula:

$$
\left(\mathrm{SM}_{\text {Hafter WSL }} / \mathrm{SMH}_{\text {after treatment }}\right) * 100 \text {. }
$$

\section{Statistical analysis}

One-way ANOVA and Tukey's tests were applied on sound enamel and after demineralization (WSL) data, in order to evaluate if values were evenly distributed among the groups before treatments. After treatments, statistical analysis was applied on $\% \mathrm{SMH}$ alteration values. A significance level of $5 \%$ was set. Analyses were performed with statistical software STATISTICA for Windows (Stat Soft Inc, Tulsa, OK, USA).

\section{RESULTS}

The SMH values for sound enamel, demineralized enamel (WSL), after treatments and the \%SMH alteration are shown in Table II. Non-significant differences were observed in sound enamel SMH values $(p=0.187)$ and in SMH values after WSL formation (p $=0.999$ ). The \%SMH alteration comparing mean values after WSL and after treatments showed significant differences among the groups $(\mathrm{p}=0.001)$. The mean values $(\mathrm{SD})$ of $\% \mathrm{SMH}$ alteration and results of Tukey's test are presented in Table II and Figure 1. 
Among the products tested, only Profluorid and Fluor Protector groups showed non-significant differences when compared to the control group. The varnishes Bifluorid 12, Clinpro White Varnish and Duraphat showed lower \%SMH alteration compared to the control group, demonstrating higher WSL remineralizing capacity.

Table II - Mean values ( \pm SD) of SMH at baseline, after WSL, after treatment and \% of SMH alteration. Statistical analyses were applied on baseline, WSL, and \%SMH alteration values (different letters show significant differences in columns $p<0.05)$

\begin{tabular}{|ccccc|}
\hline Groups & $\begin{array}{c}\text { Baseline } \\
\text { (mean } \pm \text { SD) }\end{array}$ & $\begin{array}{c}\text { WSL } \\
(\text { mean } \pm \text { SD) }\end{array}$ & $\begin{array}{c}\text { Treatment } \\
(\text { mean } \pm \text { SD) }\end{array}$ & $\begin{array}{c}\text { \% Alteration } \\
\text { (mean } \pm \text { SD) }\end{array}$ \\
\hline Control & $327.05 \pm 19.77^{\mathrm{a}}$ & $83.41 \pm 26.96^{\mathrm{a}}$ & $88.94 \pm 23.68$ & $92.40 \pm 12.10^{\mathrm{a}}$ \\
\hline Profluorid & $341.39 \pm 22.37^{\mathrm{a}}$ & $83.47 \pm 23.93^{\mathrm{a}}$ & $93.63 \pm 23.38$ & $88.66 \pm 10.66^{\mathrm{a}}$ \\
\hline $\begin{array}{c}\text { Fluor } \\
\text { Protector }\end{array}$ & $348.40 \pm 27.36^{\mathrm{a}}$ & $83.89 \pm 23.6^{\mathrm{a}}$ & $97.95 \pm 20.28$ & $85.90 \pm 14.49^{\mathrm{ab}}$ \\
\hline Bifluorid 12 & $327.79 \pm 17.48^{\mathrm{a}}$ & $84.07 \pm 24.93^{\mathrm{a}}$ & $126.01 \pm 27.01$ & $67.85 \pm 17.86^{\mathrm{bc}}$ \\
\hline Clinpro WV & $330.09 \pm 19.84^{\mathrm{a}}$ & $84.55 \pm 24^{\mathrm{a}}$ & $127.86 \pm 17.07$ & $66.60 \pm 18.48^{\mathrm{c}}$ \\
\hline Duraphat & $337.30 \pm 21.51^{\mathrm{a}}$ & $83.13 \pm 23.65^{\mathrm{a}}$ & $142.01 \pm 37.55$ & $58.62 \pm 8.69^{\mathrm{c}}$ \\
\hline
\end{tabular}

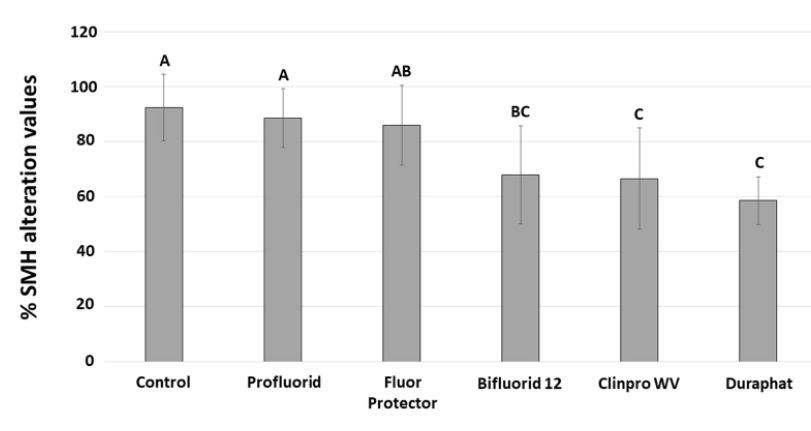

Figure 1 - Knoop SMH values (mean \pm SD) for all groups after treatments. Different letters mean statistically significant differences.

\section{DISCUSSION}

In this study, we evaluated the efficacy of fluoride varnishes containing different active ingredients in its formulation on enamel remineralization using the SMH analysis. Microhardness has been widely used for measuring enamel demineralization over the years, because it is simple, quick, and nondestructive, enabling the measurement of the specimens in different times of the study [19]. Nevertheless, a limitation of this study is that indentations were performed only on the specimens' surface and thus, are not able to detail the subsurface changes [20]. Significant differences on surface microhardness were found after treatment of WSL with the different products, thus, the null hypothesis was rejected. There were no significant differences in SMH means after artificial carious lesions regarding to the specimens allocated to the different treatment groups, showing the homogeneous distribution of the demineralized specimens among the tested groups.

The comparison between the SMH of WSL and the values obtained after treatment with the varnishes was performed to assess the ability of each product to remineralize incipient enamel lesions, and lower values of $\%$ SHM alteration means higher remineralizing ability. Our results demonstrated a significantly lower surface microhardness alteration of the specimens exposed to Bifluorid $12^{\mathrm{TM}}$, Clinpro White Varnish ${ }^{\mathrm{TM}}$, and Duraphat ${ }^{\mathrm{TM}}$ products.

The application of the 5\% NaF-based varnish (Duraphat ${ }^{\mathrm{TM}}$ ) resulted in significantly higher $\mathrm{SMH}$ of the incipient caries lesions when compared to saliva, Profluorid ${ }^{\mathrm{TM}}(5 \%$ $\mathrm{NaF})$ and Fluor Protector ${ }^{\mathrm{TM}}(0.2 \% \mathrm{NaF}+0.9 \%$ Difluorosilane). This was somehow expected considering that this product is known as the gold standard commercial varnish for prevention and treatment of dental caries [21]. The efficacy of Duraphat ${ }^{\mathrm{TM}}$ has been attributed to its proven ability to form $\mathrm{CaF}_{2}$-like reservoirs by the interaction of fluoride present in its formulation with dental minerals, which allows the formation of $\mathrm{CaF}_{2}$-like deposits on enamel surface [22]. The fluoride released from $\mathrm{CaF}_{2}-$ like deposits during biofilm $\mathrm{pH}$ drop can replace tooth hydroxyapatite mineral loss in the form of fluorapatite decreasing further demineralization and enhancing remineralization processes [23]. The reaction with enamel is proved to be timedependent, reaching its maximum effectiveness after $24 \mathrm{~h} \mathrm{[16],} \mathrm{and} \mathrm{it} \mathrm{is} \mathrm{usually} \mathrm{recommended} \mathrm{by}$ clinicians to be left over tooth surface overnight before brushing [24]. Although effective, this product presents as disadvantages the yellowish 
color of the film formed on dental structure, and sticky texture that difficult the application over all tooth surface area [24]. Also, its use has been related to potential stain of dental restorations by penetration of the product in marginal micro cracks or surface defects [25].

Bifluorid $12^{\mathrm{TM}}$ and Clinpro White varnish $^{\mathrm{TM}}$, which contain calcium and calcium + phosphate, respectively, in their compositions, presented similar results to Duraphat ${ }^{\mathrm{TM}}(5 \%$ $\mathrm{NaF}$ ). The combination of $6 \% \mathrm{NaF}$ and $6 \% \mathrm{CaF}_{2}$ present in Bifluorid $12^{\mathrm{TM}}$ is intended to favor the formation of a calcium fluoride-like layer, as an attempt to provide a strong and lasting fluoride release [26]. Despite of offering more calcium binding sites for fluoride, the presence of $\mathrm{CaF}_{2}$ in product's composition did not increase the amount of $\mathrm{CaF}_{2}$ deposits on enamel surface [26] and thus, did not improve the varnish remineralization potential compared to the $\mathrm{NaF}$ only product, as also observed in a previous clinical study [6].

Although the literature shows no significant difference in the protective effect comparing calcium-enriched fluoride varnishes with NaF only, additional measurements of loosely bound fluoride on tooth surface, as well as fluoride uptake by enamel may be necessary to investigate its potential of forming additional calcium fluoride deposits on tooth surface [8].

Clinpro White varnish presents a lower concentration of insoluble and soluble fluoride than Duraphat [27]. Despite of this, it showed similar efficacy on enamel remineralization, which is in accordance with the literature $[5,8]$. This finding might be explained by the fact that a high amount of calcium and phosphate from this product is readily available for interaction with dental tissues [5,8]. The inclusion of the functionalized TCP ingredient in $\mathrm{NaF}$ formulations seems to result in a more acidresistant mineral when compared to fluoride alone [28], due to its capacity to release calcium and phosphate when in contact with saliva, increasing the amount of these minerals. It has been also reported that NaF/TCP varnish shows higher efficacy in inhibiting incipient enamel lesions than NaF only varnish [29].

Fluoride interaction with enamel has been shown to decrease exponentially with time, and the presence of TCP might help to extend fluoride interaction with enamel, therefore enhancing lesion remineralization [30] due to its low viscosity that facilitates its contact with tooth surface. As the material deposits over all tooth surfaces, more varnish is supposed to be exposed to saliva, which would allow more calcium, phosphate and fluoride to be released on tooth surface. Nevertheless, no significant difference was found for Duraphat and Clinpro White Varnish ${ }^{\mathrm{TM}}$. It may be pointed out, as an advantage of this product, that the whitish color of the layer applied to the tooth, favors its esthetic appearance.

The other product composed of 5\% $\mathrm{NaF}$ tested in this study was Profluorid ${ }^{\mathrm{TM}}$. It is commercially available in a single application tube with different flavors. This varnish showed significantly lower ability to remineralize incipient caries lesions than Bifluorid ${ }^{\mathrm{TM}}$, ClinPro White Varnish ${ }^{\mathrm{TM}}$ and Duraphat ${ }^{\mathrm{TM}}$. Even though the percentage of sodium fluoride found in Profluorid $^{\mathrm{TM}}$ and Duraphat ${ }^{\mathrm{TM}}$ is similar, the difference in remineralizing potential might be attributed to the distinct levels of fluoride released and interactions with enamel by the different varnishes, which can affect their behavior. The different types of additives or resin carriers (e.g. natural vs. synthetic) used to formulate the varnishes are shown to influence fluoride ion diffusion $[5,8]$.

The varnish containing $0.9 \%$ difluorsilane and polyurethane as base with ethyl acetate and isoamyl propionate solvents, showed lower effective remineralizing potential, similar to artificial saliva and Profluorid ${ }^{\mathrm{TM}}$. This might be related to the low concentration of fluoride (0.1\%), which according to the manufacturer, is equivalent to $1000 \mathrm{ppm}$ in solution and concentrate on the tooth surface as the solvents evaporate.

Although the comparison among the different tested products is difficult to achieve, 
three out of five products tested (Bifluorid $12^{\mathrm{TM}}$, Clinpro White Varnish ${ }^{\mathrm{TM}}$ and Duraphat ${ }^{\mathrm{TM}}$ ) were able to promote remineralization of WSL. Nevertheless, it has to be highlighted that some aspects found in in vivo conditions, such as salivary flow clearance and lesion depth may directly influence varnishes role in de/ remineralization process, and thus must be considered in further studies.

\section{CONCLUSION}

Based on the limitations of this in vitro study, it could be concluded that the varnishes Bifluorid $12^{\mathrm{rm}}(6 \% \mathrm{NaF}+6 \% \mathrm{CaF} 2)$, Clinpro White Varnish $^{\mathrm{TM}}(5 \% \mathrm{NaF}+5 \% \mathrm{TCP})$ and Duraphat $^{\mathrm{TM}}(5 \% \mathrm{NaF})$ were able to effectively remineralize WSL, in contrast to Profluorid ${ }^{\mathrm{TM}}$ $(5 \% \mathrm{NaF})$ and Fluor Protector ${ }^{\mathrm{TM}}(0.2 \% \mathrm{NaF}$ $+0.9 \%$ difluorsilane). However, none of the products tested were able to recover the baseline microhardness of sound enamel.

\section{Acknowledgments}

\section{N/A}

\section{Funding}

This study was partially supported by CAPES - Coordination for the Improvement of Higher Education Personnel

\section{Conflict of interest}

The authors have no proprietary, financial, or other personal interest of any nature or kind in any product, service, and/or company that is presented in this article.

\section{Regulatory Statement}

$$
\text { N/A }
$$

\section{REFERENCES}

1. Marinho VC, Higgins JP, Logan S, Sheiham A. Fluoride varnishes for preventing dental caries in children and adolescents. Cochrane Database Syst Rev. 2002;(3):CD002279. doi:10.1002/14651858.CD002279. Update in: Cochrane Database Syst Rev. 2013;7:CD002279. PMID: 12137653.

2. Tenuta LM, Cerezetti RV, Del Bel Cury AA, Tabchoury CP, Cury JA. Fluoride release from CaF2 and enamel demineralization. J Dent Res. 2008 Nov;87(11):1032-6. doi: 10.1177/154405910808701105. PMID: 18946010.
3. Bruun C, Givskov H. Formation of CaF2 on sound enamel and in caries-like enamel lesions after different forms of fluoride applications in vitro. Caries Res. 1991;25(2):96-100. doi: 10.1159/000261350. PMID:2059982.

4. Ogard B, SeppäL, Rølla G. Professional topical fluoride applications--clinical efficacy and mechanism of action. Adv Dent Res. 1994 Jul;8(2):190-201. doi: 10.1177/08959374940080021001.PMID: 7865075.

5. Al Dehailan L, Martinez-Mier EA, Lippert F. The effect of fluoride varnishes on caries lesions: an in vitro investigation. Clin Oral Investig. 2016 Sep;20(7):1655-62. doi: 10.1007/s00784-015-1648-4. Epub 2015 Nov 10. PMID: 26556573.

6. Ferreira JM, Aragão AK, Rosa AD, Sampaio FC, Menezes VA. Therapeutic effect of two fluoride varnishes on white spot lesions: a randomized clinical trial. Braz Oral Res. 2009 0ct-Dec;23(4):446-51. doi: 10.1590/s180683242009000400015. PMID:20027453.

7. Soares-Yoshikawa AL, Varanda T, Iwamoto AS, Kantovitz KR, Puppin-Rontani $\mathrm{RM}$, Pascon FM. Fluoride release and remineralizing potential of varnishes in early caries lesions in primary teeth. Microsc Res Tech. 2021 May;84(5):10121021. doi: 10.1002/jemt.23662. Epub 2020 Dec 5. PMID:33278320.

8. Dehailan LA, Martinez-Mier EA, Eckert GJ, LippertF. An In Vitro Investigation of Anticaries Efficacy of Fluoride Varnishes. Oper Dent. 2019 Sep/ Oct;44(5):E234-E243. doi: 10.2341/18-040-L. Epub 2019 Jun 7.PMID: 31172870.

9. Jain A, Suprabha BS, Shenoy R, Natarajan S, Rao A. Remineralising Effectiveness of Two Fluoride Varnishes Containing Additives: An In Vitro Study. Oral Health Prev Dent. 2019;17(4):385-393. doi: 10.3290/j.ohpd.a42686. PMID: 31204393.

10. Spinola MDS, Moecke SE, Rossi NR, Nakatsuka T, Borges AB, Torres CRG Efficacy of S-PRG filler containing varnishes on enamel demineralization prevention. Sci Rep. 2020 Nov 4:10(1):18992. doi: 10.1038/s41598-02076127-w. PMID:33149256; PMCID:PMC7642416.

11. Punathil S, Pulayath CV, Ismail SP, Bavabeedu SS, Moyin S, Uthappa R. Assessment of Enamel Surface Microhardness with different Fluoride Varnishes-An In Vitro Study. J Contemp Dent Pract. 2018 Nov 1;19(11):13171321. PMID: 30602634.

12. Rocha Gomes Torres C, Borges AB, Torres LM, Gomes IS, de Oliveira RS. Effect of caries infiltration technique and fluoride therapy on the colour masking of white spot lesions. J Dent. 2011 Mar;39(3):202-7. doi:10.1016/j. jdent.2010.12.004. Epub 2010 Dec 21. PMID: 21172402.

13. Ávila DMDS, Augusto MG, Zanatta RF, Scaramucci T, Aoki IV, Torres CRG, Borges AB. Enhancing the Anti-Erosive Properties of Fluoride and Stannous with the Polymer Carbopol. Caries Res. 2020;54(3):250-257. doi: 10.1159/000506467. Epub 2020 Sep 3.PMID:32882696.

14. Buskes JA, Christoffersen J, Arends J. Lesion formation and lesion remineralization in enamel under constant composition conditions. A new technique with applications. Caries Res. 1985;19(6):490-6. doi: 10.1159/000260887.PMID:3865704.

15. Wierichs RJ, Stausberg S, Lausch J, Meyer-Lueckel H, Esteves-OliveiraM. Caries-Preventive Effect of NaF, NaF plus TCP,NaF plus CPP-ACP, and SDF Varnishes on Sound Dentin and Artificial Dentin Caries in vitro. Caries Res. 2018;52(3):199-211. doi: 10.1159/000484483. Epub 2018 Jan 17.PMID:29339648.

16. Fernández CE, Tenuta LM, Zárate P, Cury JA. Insoluble NaF in Duraphat may prolong fluoride reactivity of varnish retained on dental surfaces. Braz Dent J. 2014;25(2):160-4. doi: 10.1590/0103-6440201302405. PMID:25140722.

17. Queiroz CS, Hara AT, Paes Leme AF, Cury JA. pH-cycling models to evaluate the effect of low fluoride dentifrice on enamel de- and remineralization. Braz Dent J.2008;19(1):21-7. doi:10.1590/s0103-64402008000100004.PMID: 18438555 . 
18. ten Cate JM, Duijsters PP. Alternating demineralization and remineralization of artificial enamel lesions. Caries Res. 1982;16(3):201-10. doi: 10.1159/000260599. PMID: 6953998

19. Featherstone JD, ten Cate JM, Shariati M, Arends J. Comparison of artificial caries-like lesions by quantitative microradiography and microhardness profiles. Caries Res. 1983;17(5):385-91. doi: 10.1159/000260692.PMID: 6577953.

20. Magalhães AC, Moron BM, Comar LP, Wiegand A, Buchalla W, Buzalaf MA. Comparison of cross-sectional hardness and transverse microradiography of artificial carious enamel lesions induced by different demineralising solutions and gels. Caries Res. 2009;43(6):474-83. doi: 10.1159/000264685. Epub 2009 Dec 10. PMID:20016178.

21. Cardoso CA, Cassiano LP, Costa EN, Souza-E-Silva CM, Magalhães AC, Grizzo LT, Caldana ML, Bastos JR, Buzalaf MA. Effect of xylitol varnishes on remineralization of artificial enamel caries lesions in situ. J Dent. 2016 Jul;50:74-8. doi:10.1016/j.jdent.2016.03.011. Epub 2016 Mar 23. PMID: 27032722.

22. ten Cate JM. Review on fluoride, with special emphasis on calcium fluoride mechanisms in caries prevention. Eur J Oral Sci. 1997 0ct;105(5 Pt2):461-5. doi: 10.1111/.j.1600-0722.1997.tb00231.x. PMID: 9395110.

23. Cury JA, Tenuta LM. How to maintain a cariostatic fluoride concentration in the oral environment. Adv Dent Res. $2008 \mathrm{Jul} 1$;20(1):13-6. do: 10.1177/154407370802000104. PMID: 18694871.

24. Noble J. Fluoride varnish for the teeth. Vital. 2008:5:39. doi:10.1038/vital739
25. Debner T, Warren DP,Powers JM. Effects of fluoride varnish on color of esthetic restorative material. JEsthet Dent. 2000;12(3):160-3. doi: 10.1111/j.1708-8240.2000.tb00215.x. PMID: 11324084 .

26. Attin T, Hartmann 0, Hilgers RD, Hellwig E. Fluoride retention of incipient enamel lesions after treatment with a calcium fluoride varnish in vivo. Arch Oral Biol. 1995 Mar;40(3):169-74. doi: 10.1016/0003-9969(95)98804-8. PMID: 7605244.

27. Godoi FA, Carlos NR, Bridi EC, Amaral FLBD, Franca FMG, Turssi CP, Kantovitz $\mathrm{KR}$, Basting RT. Remineralizing effect of commercial fluoride varnishes on artificial enamel lesions. Braz Oral Res. 2019 May 27:33:e044. doi: 10.1590/1807-3107bor-2019.vol33.0044.PMID:31141037.

28. Almeida MQ, Costa OX, Ferreira JM, Menezes VA, Leal RB, Sampaio FC Therapeutic potential of Brazilian fluoride varnishes: an in vivo study. Braz Dent J. 2011;22(3):193-7. doi: 101590/s0103-64402011000300003. PMID: 21915515.

29. Rirattanapong P, Vongsavan K, Saengsirinavin C, Pornmahala T. Effect of fluoride varnishes containing tri-calcium phosphate sources on remineralization of initial primary enamel lesions. Southeast Asian J Trop Med Public Health. 2014 Mar;45(2):499-504. PMID: 24968692.

30. Mensinkai PK, Ccahuana-Vasquez RA, Chedjieu I, Amaechi BT, Mackey AC Walker TJ, Blanken DD, Karlinsey RL. In situ remineralization of white-spot enamel lesions by 500 and 1,100 ppm F dentifrices. Clin Oral Investig. 2012 Aug;16(4):1007-14. doi: 10.1007/s00784-011-0591-2. Epub 2011 Jul 13. PMID: 21750917.

\section{Alessandra Buhler Borges \\ (Corresponding address)}

São Paulo State University (Unesp), Institute of Science and Technology, Department of Restorative Dentistry, São José dos Campos, Brazil.

Av. Eng. Francisco José Longo, 777 - Jardim São Dimas - São José dos Campos/SP CEP 12245-00

Email: alessandra@fosjc.unesp.br

Date submitted: 2020 Aug 31

Accept submission: 2020 Dec 18 